\title{
Short communication: Production of antimicrobial peptide S100A8 in the goat mammary gland and effect of intramammary infusion of lipopolysaccharide on S100A8 concentration in milk
}

\author{
F. Y. Purba, T. Nii, Y. Yoshimura, and N. Isobe* \\ Graduate School of Biosphere Science, Hiroshima University, Higashi-Hiroshima, 739-8528, Japan
}

\section{ABSTRACT}

This study aimed to determine the production site of antimicrobial peptide S100A8 in the goat mammary gland and changes in its concentration in milk after lipopolysaccharide (LPS) challenge. Sixteen Tokara goats were used in this study for mammary gland tissue, blood leukocyte, and milk somatic cell collection and LPS challenge. The mRNA expression and protein localization of S100A8 in the mammary gland parenchyma and teat, blood leukocytes, and milk somatic cells were examined by reverse-transcription PCR and immunohistochemistry. The S100A8 concentration in milk was measured at 0 to $144 \mathrm{~h}$ after intramammary challenge of LPS by enzyme immunoassay. The mRNA of S100A8 was expressed in the parenchyma and teat, leukocytes isolated from blood, and milk somatic cells. Antimicrobial peptide S100A8 was immunolocalized in the outermost layer of the teat skin of udders with and without LPS infusion, whereas in the mammary gland it was immunolocalized only in the leukocytes infiltrated in the alveoli after LPS infusion. Antimicrobial peptide S100A8 was also immunolocalized in the blood and milk leukocytes. The number of S100A8-positive cells in milk was higher than that in blood. The concentration of S100A8 in milk increased significantly at $72 \mathrm{~h}$ after intramammary infusion of LPS. These results suggest that S100A8 is produced in the leukocytes and that its secretion into milk is affected by LPS stimulation.

Key words: antimicrobial peptide, S100A8, mastitis, leukocyte

\section{Short Communication}

Mastitis, the inflammatory process of the mammary gland, is one of the most important diseases in small ruminants as well as bovines with regard to economic,

Received July 17, 2018.

Accepted January 21, 2019.

*Corresponding author: niso@hiroshima-u.ac.jp food hygiene (Bergonier and Berthelot, 2003; Dore et al., 2016), and animal welfare (Dore et al., 2016) perspectives. The prevalence of mastitis in small ruminants ranges from 5 to 30\% (Bergonier and Berthelot, 2003; Contreras et al., 2003) and is expressed in clinical and subclinical forms (Bergonier et al., 2003). Small ruminant mastitis is mainly caused by bacteria, with CNS identified as the most frequent isolates (Contreras et al., 2007; Zhao et al., 2015; Dore et al., 2016). However, mastitis can also be caused by Escherichia coli or other gram-negative bacteria, and it is often characterized by acute and severe inflammation (Vangroenweghe et al., 2005).

The host defense mechanism against infection is orchestrated in many different steps and varies individually based on the natural ability of the host to resist infection. The elimination process of pathogens from the mammary gland is somehow managed by responses that occur immediately after initial infection (Bannerman, 2009), which compose the innate immune system that initiates the detection and proinflammatory response to pathogens. Antimicrobial peptides (AMP) are the components of the innate immune system that possess antimicrobial activity against a wide range of pathogens (Bahar and Ren, 2013). The expression and role of some AMP were clearly demonstrated, such as lingual AMP (Swanson et al., 2004; Isobe et al., 2009a, b), lactoferrin (Huang et al., 2012; Isobe et al., 2013), psoriasin (Regenhard et al., 2010; Zhang et al., 2014a), and cathelicidins (Smolenski et al., 2011; Zhang et al., 2014b; Srisaikham et al., 2016), which play important roles in host mammary gland defense system.

Another family of AMP is S100A8 or calgranulin A, belonging to the S100 protein group, which exerts an antimicrobial activity by chelating several ions required for microbial growth (Corbin et al., 2008). This protein became an interesting research focus due to its abundant concentration in cytosol and calcium-binding capacity in phagocytes (Kerkhoff et al., 1998). In humans and mice, S100A8 and S100A9 are mainly expressed in neutrophils, together constituting approximately $45 \%$ of neutrophils in the cytosol (Edgeworth et al., 
1991). One or both can be induced in other types of cells, such as monocytes or macrophages (Xu et al., 2001; Hsu et al., 2005), endothelial cells (McCormick et al., 2005), and keratinocytes (Eckert et al., 2004). Some in vitro experiments report calgranulin as one of the most upregulated genes related to several inflammatory diseases and inflammation-associated cancers (Gebhardt et al., 2006; Srikrishna, 2012). Furthermore, the production and secretion of calgranulins were stimulated by various proinflammatory factors such as IFN- $\gamma$, TNF- $\alpha$ (Mørk et al., 2003), IL-1 $\alpha$ (Hayashi et al., 2007), and IL-10 (Hsu et al., 2005), whereas they were reduced by transforming growth factor- $\beta$ (Hayashi et al., 2007).

In ruminants, gene expression of S100A 8 was also detected in milk somatic cells in response to Staphylococcus aureus infection of mammary glands in goats (Cremonesi et al., 2012) and Streptococcus uberis infection in sheep (Addis et al., 2013), with a log fold increase of 3.4 and 1.86 after infection, respectively. The goat is an appropriate animal model to study the immune system in the mammary gland of small ruminants; however, no previous study has demonstrated S100A8 expression in the mammary gland and whether it is secreted into the milk. This study was aimed at determining the mRNA expression of S100A8 in goat mammary glands, leukocytes from blood, and milk somatic cells to reveal the protein localization and its secretion into the milk.

Sixteen Tokara goats (BW: 20-25 kg, parity 1-4, mid-lactation stage, milk yield: $300-800 \mathrm{~mL} / \mathrm{d}$ ) were used in this study. Goats were fed $0.6 \mathrm{~kg}$ of hay cubes and $0.2 \mathrm{~kg}$ of barley per day and had free access to water and a trace mineralized salt block. Diets were offered 2 times daily at 0800 and $1500 \mathrm{~h}$. Five goats were used for mammary gland tissue, milk somatic cell, and blood leukocyte collection for S100A8 mRNA expression by PCR. Three goats were used as udder models, intramammarily infused with unilateral LPS, and then killed for tissue collection from both sides. The other 8 goats were intramammarily infused with LPS and examined for S100A8 concentration in milk until $144 \mathrm{~h}$ after infusion. Only goats with low SCC $\left(<1,000 \times 10^{3}\right.$ cells $/ \mathrm{mL}$ ) in milk were selected for LPS challenge. Normal goat milk SCC varies between $270 \times 10^{3}$ and 2,000 $\times 10^{3}$ cells $/ \mathrm{mL}$ (Paape et al., 2001), which is higher than other species because its milk secretion is apocrine (Souza et al., 2012). This formation is characterized by the detachment of the apical part of the epithelial cells, referred as cytoplasmic particles, from their base at the end of the secretory phase and their release into the alveolar lumen (Perrin and Baudry, 1993). This study was conducted in accordance with the guidelines for animal experiments of Hiroshima University, Japan.
Mammary gland tissues, including the parenchyma and teat, were obtained within 20 min after killing by exsanguination under sedation with xylazine (Bayer HealthCare, Osaka, Japan) and anesthesia with pentobarbital (Somnopentyl; Kyoritsu Seiyaku Corp., Tokyo, Japan). The tissues were frozen at $-80^{\circ} \mathrm{C}$ until examination of mRNA expression of S100A8 by reverse-transcription PCR or fixed in neutralized $10 \%$ (vol/vol) formalin in PBS for protein localization by immunohistochemistry.

Ten milliliters of blood was collected from the jugular vein of goats, transferred to an anticoagulated tube with heparin, and centrifuged at $268 \times g$ for $10 \mathrm{~min}$ at $4^{\circ} \mathrm{C}$. Plasma was removed from the tube, buffy coat was transferred into a new tube, and double-distilled $\mathrm{H}_{2} \mathrm{O}$ was added to rupture red blood cells, leaving leukocytes (Zhang et al., 2014b). Milk was collected from the goat udder by hand-milking and centrifuged at 1,677 $\times g$ for 5 min at $4^{\circ} \mathrm{C}$. Milk fat and skim milk were removed, leaving milk somatic cells (Nishikawa et al., 2018). Skim milk was stored for enzyme immunoassay, and a part of cells pellet was resuspended in PBS for measurement of SCC with a Countess Automated Cell Counter (Life Technologies Japan Co. Ltd., Tokyo, Japan). Blood leukocytes and milk somatic cells from uninfused goats were used for mRNA expression of S100A8 by PCR and protein localization by immunohistochemistry. To identify the S100A8 protein in milk somatic cells, milk somatic cells pellet was homogenized in $1 \mathrm{~mL}$ of PBS for $1 \mathrm{~min}$. After centrifugation, the resulting supernatant was used for enzyme immunoassay.

Total RNA of mammary gland tissues, blood leukocytes, and milk somatic cells was isolated with SepasolRNA I Super (Nacalai Tesque Inc., Kyoto, Japan). Pelleted RNA was dissolved in TE buffer $(10 \mathrm{~m} M$ Tris- $\mathrm{HCl}$, $\mathrm{pH}$ 8.0; $1 \mathrm{~m} M$ EDTA) and kept at $-80{ }^{\circ} \mathrm{C}$ until use. The RNA samples were treated with RQ1 RNase-free DNase (Promega Co., Madison, WI) as reported previously (Zhang et al., 2014a,b). The quality and quantity of the RNA were measured with a GeneQuant pro serial 80-2114-98 spectrophotometer (Biochrome Ltd., Cambridge, UK). The quality of RNA was assessed by examining the RNA ratio $(260 / 280)$. The ratios of RNA 260/280 were $1.994 \pm 0.034$ in mammary gland tissues, $2.0956 \pm 0.026$ in teat tissues, $1.9588 \pm 0.036$ in blood leukocytes, and $1.8374 \pm 0.079$ in milk somatic cells. The number of biological replicates was 5 for each sample. Purified RNA samples were reverse transcribed using ReverTra Ace (Toyobo Co. Ltd., Osaka, Japan). Total RNA isolation and cDNA synthesis followed the manufacturer's instructions.

The PCR amplification was carried out in a programmable thermal controller using a $20-\mu \mathrm{L}$ reaction 
mixture containing $0.5 \mu M$ specific primers, a $1-\mu \mathrm{L}$ aliquot of cDNA, $1 \times$ KAPATaq Extra Buffer, $2 \mathrm{mM}$ $\mathrm{MgCl}_{2}, 0.3 \mathrm{mM}$ dNTP mixture, and $1.25 \mathrm{U}$ KAPATaq Ex DNA Polymerase (Kapa Biosystems, Wilmington, MA). Target gene expression was examined by reversetranscription PCR using S100A8 goat-specific primers 5'-AAGGGAATTACCACGCCGTC-3' for forward and $5^{\prime}$-TGTGAATGTCTTCATGGGCTGC-3' for reverse (accession no. XM_005677513). The same primer pairs described above were used for sequencing. Amplified PCR products were used for the direct sequencing method with the 3130xl Genetic Analyzer (Applied Biosystems, Foster City, CA) and confirmed to be identical to the goat S100A8 sequence reported in NCBI (https://www.ncbi.nlm.nih.gov), as described in Figure 1. The PCR reaction was conducted under the following conditions: denaturation cycle at $94^{\circ} \mathrm{C}$ for $2 \mathrm{~min} ; 35$ cycles at $94^{\circ} \mathrm{C}$ for $15 \mathrm{~s}, 53^{\circ} \mathrm{C}$ for $15 \mathrm{~s}$, and $72^{\circ} \mathrm{C}$ for $30 \mathrm{~s}$; and a final extension at $72^{\circ} \mathrm{C}$ for $60 \mathrm{~s}$. The expression of $\beta$-actin gene $(A C T B)$ was analyzed as an internal control for reaction efficiency. The primers for the $\beta$-actin gene were 5'-CATCACCATCGGCAATGAG-3' for forward and 5'-CCGTGTTGGCGTAGAGGTC-3' for reverse (Zhang et al., 2014b). The PCR volume and reaction of $\beta$-actin were identical to the steps described above, with annealing temperature at $53^{\circ} \mathrm{C}$. The PCR products were separated electrophoretically on a $2 \%$ (wt/vol) agarose gel containing $1 \mu \mathrm{g} / \mathrm{mL}$ ethidium bromide and were examined under UV illumination.

A competitive enzyme immunoassay for S100A8 was performed using S100A8 antibody as reported previously (Elgawish et al., 2018). The S100A8 antibody was prepared in our laboratory by immunizing rabbits against synthetic S100A8 peptide consisting of 10 AA (CLEAHEIHKE). After coating with the S100A8 antibody, samples diluted with assay buffer were added to the wells, followed by horseradish peroxidase-labeled S100A8. Tetramethylbenzidine solution was added to the plate, and the optical density was measured using a microplate reader.

Mammary gland tissues were fixed, dehydrated, and then embedded in paraffin in the usual manner. Sections of $3-\mu \mathrm{m}$ thickness were air-dried on coated slides. After deparaffinization, antigen retrieval was performed by incubating sections with $20 \mu \mathrm{g} / \mathrm{mL}$ proteinase $\mathrm{K}$ for 30 min at $37^{\circ} \mathrm{C}$. Sections were washed with PBS for $10 \mathrm{~min}$ and then incubated with the anti-S100A 8 antibody (10 $\mu \mathrm{g} / \mathrm{mL}$ ) in PBS for $3 \mathrm{~h}$ at $37^{\circ} \mathrm{C}$. Sections were washed with PBS for 10 min. Immunoreaction products were identified using peroxidase-labeled goat anti-rabbit IgG antibody (Histofine, Nichirei, Tokyo, Japan) for $1 \mathrm{~h}$ at $37^{\circ} \mathrm{C}$ and then visualized by incubating the sections with diaminobenzidine reaction mixture. Sections were counterstained with hematoxylin, dehydrated, and covered. The normal rabbit IgG at $10 \mu \mathrm{g} / \mathrm{mL}$ was used to replace the anti-S100A8 antibody for the negative control.

Immunohistochemistry was also conducted to investigate the protein localization and define the number of positive cells of S100A8 in blood leukocytes and milk somatic cells from uninfused goats and milk somatic cells from infused goats. A total of 5 sample pairs (blood leukocytes and milk somatic cells) were taken from uninfused goats and 8 milk somatic cells samples were taken from infused goat at 0 to $144 \mathrm{~h}$ after LPS infusion. Cells were attached to slides and dried over-

\section{S100A8}

sequence

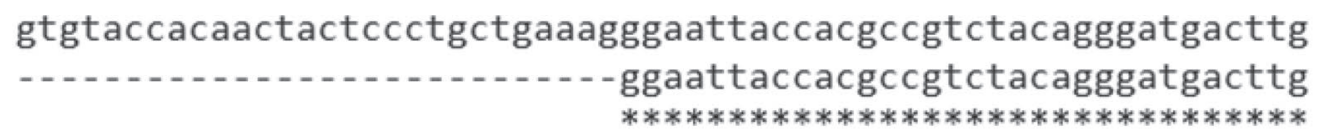

S100A8

sequence

aagagactgttagagacagagtgtcctaagtttttgaagaaaaaggatgcagacacttgg

aagagactgttagagacagagtgtcctaagtttttgaagaaaaaggatgcagacacttgg

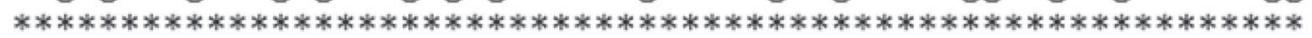

S100A8

sequence

ttcaaagagttggacatcaatcaggatggtggaattaacttcgaggagttcctcgtgctg ttcaaagagttggacatcaatcaggatggtggaattaacttcgaggagttcctcgtgctg $* * * * * * * * * * * * * * * * * * * * * * * * * * * * * * * * * * * * * * * * * * * * * * * * * * * * * * * * * * * *$

S100A8

sequence gtgataaaggtgggcctggcagcccatgaagacattcacaaagaatagcagagctatcag

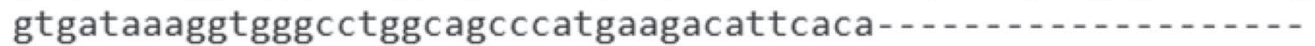
$* * * * * * * * * * * * * * * * * * * * * * * * * * * * * * * * * * * * * * * *$
600

420

32

480

92

540

152

192

Figure 1. The DNA sequences of S100A8 (XM_005677513.3) and PCR product in the present study. Sequences were the same, indicating that primers were attached in the S100A8 sequence correctly. 
night. The slides were fixed with neutralized $10 \%$ ( vol/ vol) formalin for $30 \mathrm{~min}$. Cells were washed with PBS for $10 \mathrm{~min}$ and then incubated with the anti-S100A8 antibody $(10 \mu \mathrm{g} / \mathrm{mL})$ in PBS for $3 \mathrm{~h}$ at $37^{\circ} \mathrm{C}$. Sections were washed with PBS for $10 \mathrm{~min}$. Immunoreaction products were identified using goat anti-rabbit IgG antibody conjugated to alkaline-phosphatase (SeraCare, Milford, MA) for $1 \mathrm{~h}$ at $37^{\circ} \mathrm{C}$ and then visualized by incubating the sections with ImmPACT Vector Red substrate kit (Vector Laboratories, Burlingame, CA). Cells were counterstained with hematoxylin and then covered.

For the S100A8-stained section, 5 images of blood leukocytes and milk somatic cells from uninfused goats and 8 milk somatic cells samples from infused goats were identified and imaged. Images were acquired with image analysis software (NIS-Elements D Version 4.00.12; Nikon, Tokyo, Japan) affixed to a light microscope with Nomarski filter (Eclipse E400, Nikon) with a $40 \times$ objective. Acquired images were analyzed by counting the number of positively stained S100A8 cells in an area of $7 \times 10^{5} \mu^{2}$, and only immune cells were included in the count total. Cells were simultaneously classified as being either positively or negatively stained for S100A8. This approach resulted in 100 cells being classified, and these data were used to calculate the percentages of S100A8-positive cells for each sample.

The concentration of S100A8 was measured in milk before and after infusion of LPS in mammary glands of 8 goats. After milking completely, LPS from E. coli O111:B4 (Wako Pure Chemical, Osaka, Japan) at a dose of $100 \mu \mathrm{g}$ dissolved in $5 \mathrm{~mL}$ of saline was infused, as described in previous studies (Isobe et al., 2009b; Huang et al., 2012), whereas the contralateral gland was uninfused. Milk samples were collected from both glands by hand-milking before infusion $(0 \mathrm{~h})$ and at $12,24,48,72,96,120$, and $144 \mathrm{~h}$ after infusion. Skim milk samples were stored at $-20^{\circ} \mathrm{C}$ and then used for measuring the S100A8 concentration by enzyme immunoassay.

Statistical analysis was completed using SAS software (version 9.4, SAS Institute Inc., Cary, NC). The differences in percentage of S100A8-positive cells in blood leukocytes and milk somatic cells were checked by paired TTEST procedure. The percentage and the total number (percentage of S100A8-positive cells multiplied by the number of SCC) of S100A8-positive cells in milk after LPS infusion was reported as fold change compared with the baseline value at $0 \mathrm{~h}$. The mean difference for each parameter was analyzed by 1 sample TTEST procedure. Continuous data (milk S100A8 concentration and SCC) were assessed for normality using the UNIVARIATE procedure. The $\log _{10}$-transformed value of the SCC (cells/mL of milk) was used for analysis to approximate normality. The repeated-measures analysis using the MIXED procedure of SAS was used to analyze continuous data. The repeated statement was used for repeated measurements analysis, and treatment, time, and the interactions between treatment and time after infusions were included in the models as fixed effects. The structure of covariance (autoregressive, unstructured, or compound symmetry) was chosen according to the Bayesian information criteria. A Tukey-Kramer adjustment test was performed to correct for multiple comparison. Statistical significance of the contrast analysis was defined as $P \leq 0.05$.

The S100A8 gene was expressed in the mammary gland parenchyma and teat of uninfused goats $(\mathrm{n}=$ 5; Figure 2A), but as the precise site of S100A8 was unclear, its localization was investigated by immunohistochemistry. The S100A8 protein was localized in the outermost layer of the teat skin and epidermis layer in the uninfused gland (Figure 3A and B). Human skin epithelium is known to contain some antimicrobial proteins, including lactoferrin, lysozyme, cathelicidin, RNase7, S100A7, and several $\beta$-defensins, capable of suppressing bacterial growth and contributing to the skin host-defense function (Schauber and Gallo, 2008).
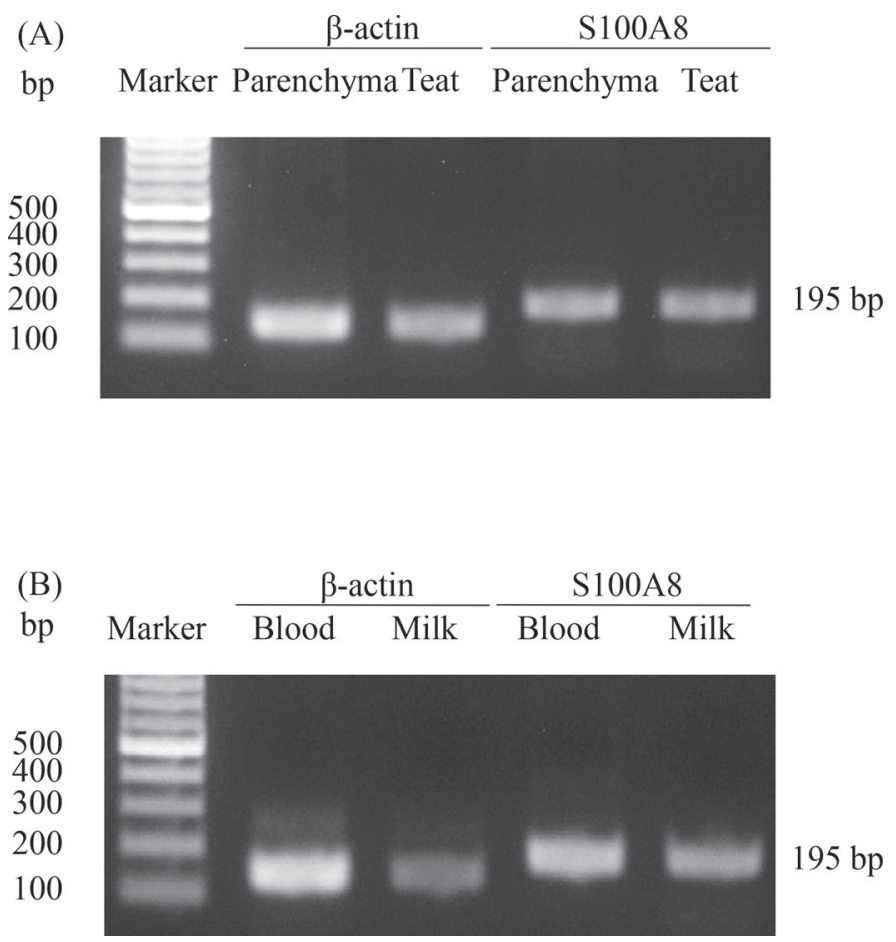

Figure 2. Messenger RNA expression of S100A8 in (A) the parenchyma and teat of the mammary gland and (B) blood leukocytes and milk somatic cells $(\mathrm{n}=5)$. 

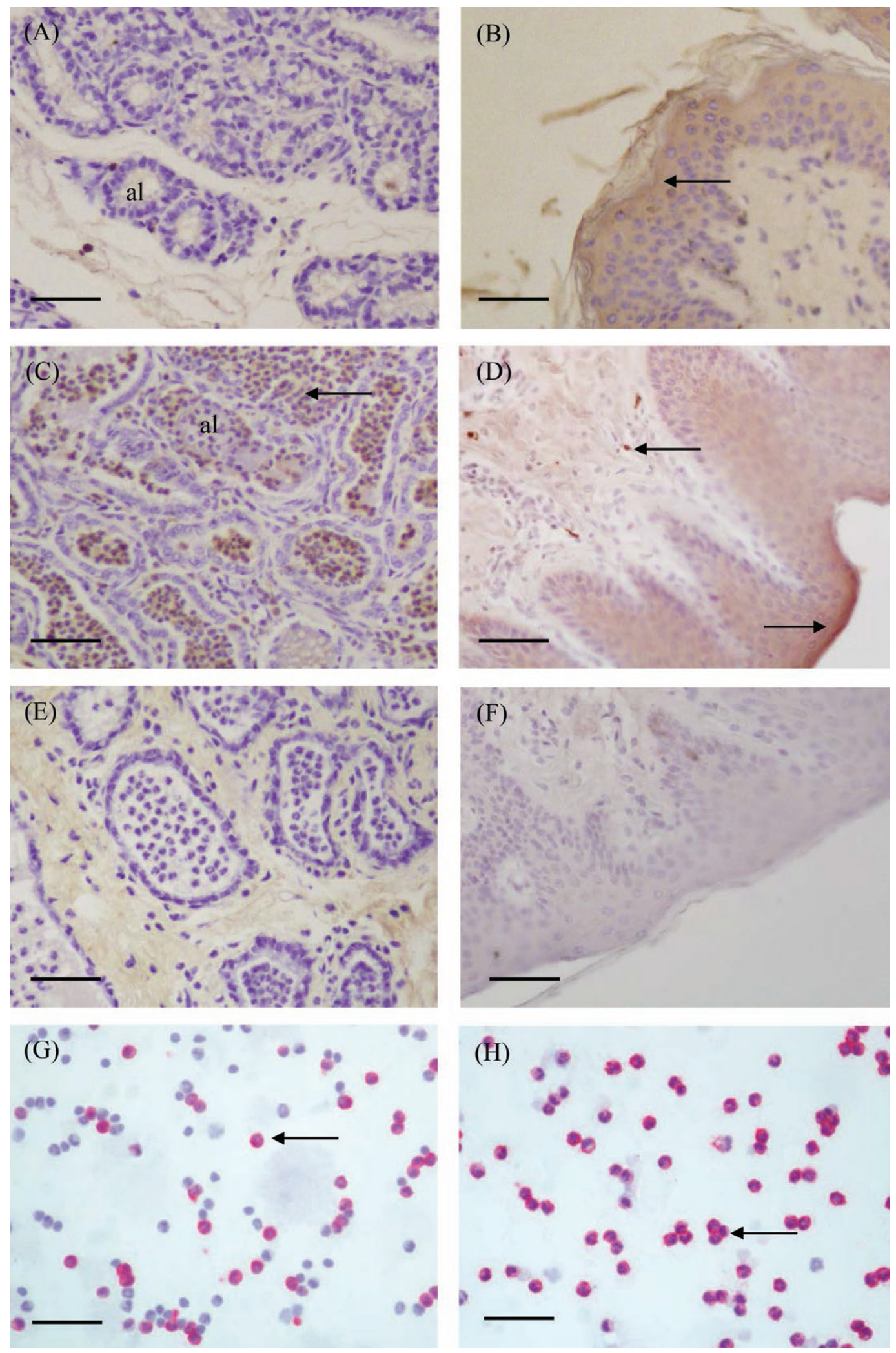

Figure 3. Representative photographs of the mammary gland, teat, and leukocytes immunostained with the S100A8 antibody $(\mathrm{n}=3$ ). Alveoli and teat from (A, B) uninfused mammary gland and (C, D) LPS-infused mammary gland. (E, F) Negative control in which the antiS100A8 antibody was replaced with normal rabbit IgG. $(\mathrm{G}, \mathrm{H})$ Leukocytes derived from blood $(\mathrm{G})$ and milk $(\mathrm{H})$ of uninfused goats. al = alveolus. Arrows show S100A8-positive reactions. Scale bars $=50 \mu \mathrm{m}$. 
In bovines and goats, the major localization site of the S100 protein family (S100A7, S100A8, S100A9, and S100A12) was observed throughout the epithelial layer of the epidermis in which keratinocytes are the predominant cell type (Zhang et al., 2014a; Smolenski et al., 2015).

(A)

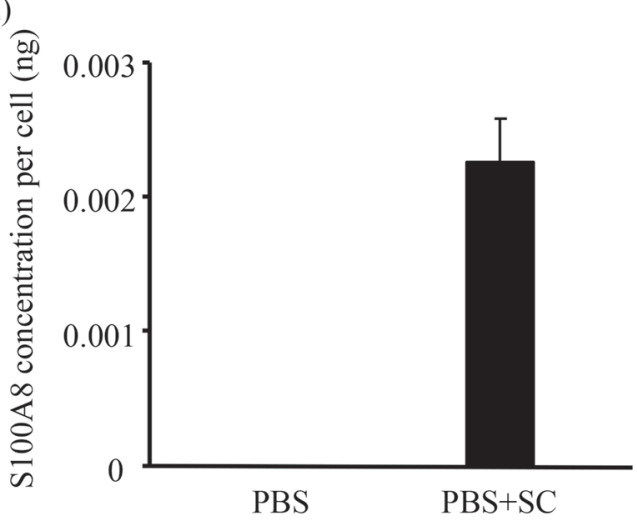

(C)

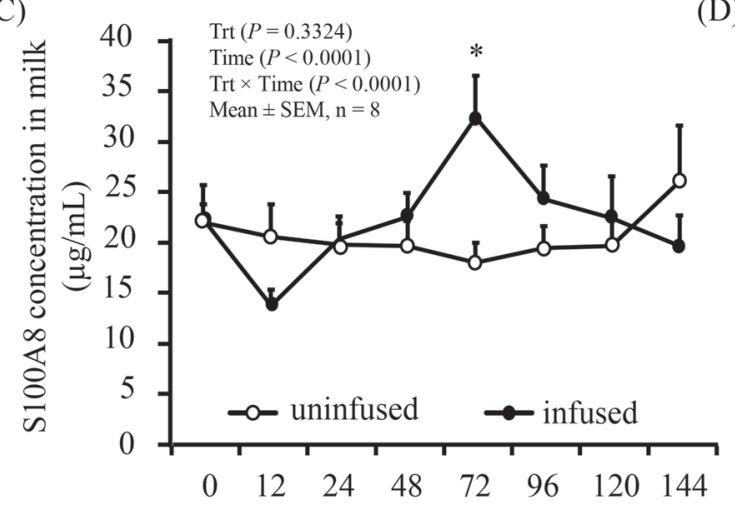

Time after infusion (h)

(E)

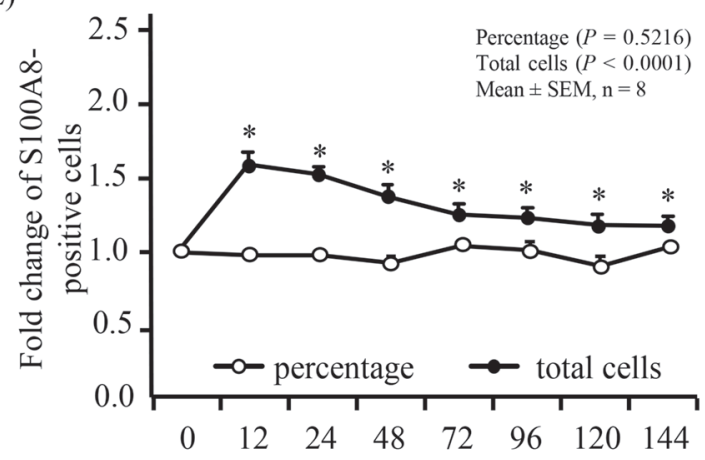

Time after infusion (h)
In the infused gland, S100A8 was not localized in the epithelial cells of alveoli but rather in the leukocytes infiltrated into the alveoli, ducts, and lamina propria of the teat (Figure 3C and D). Therefore, leukocytes from blood and milk somatic cells that contain leukocytes were isolated to precisely confirm the protein

(B)

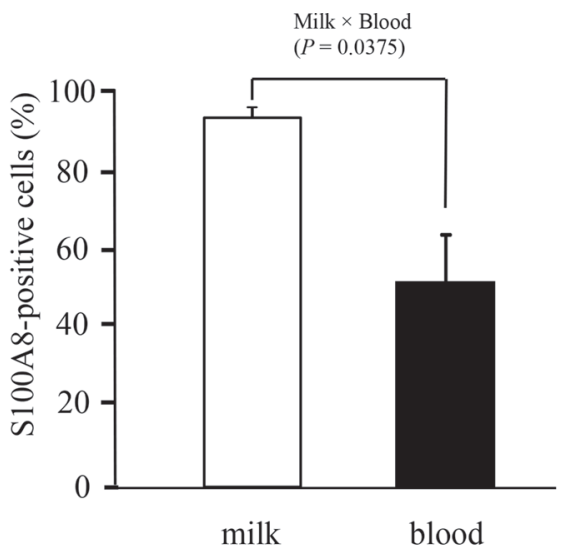

D)

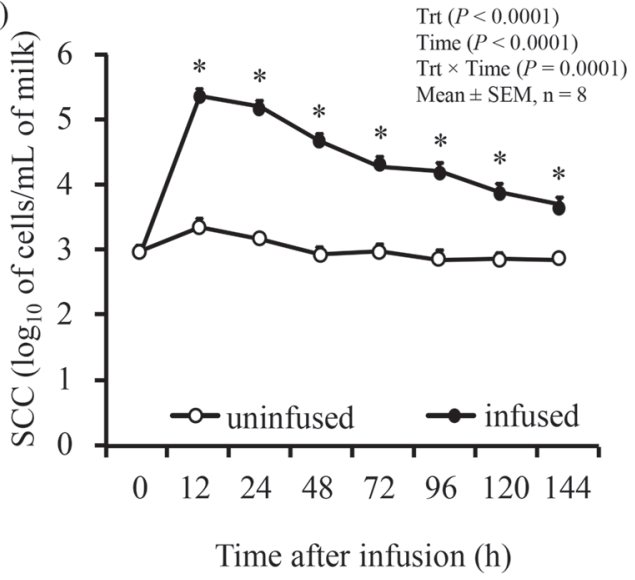

Figure 4. (A) The concentration of S100A8 in PBS with and without milk homogenized somatic cells (SC) and (B) percentage of S100A8positive cells in blood and milk $(\mathrm{n}=5, P=0.0375)$. $(\mathrm{C}-\mathrm{E})$ Changes in milk according to treatment (Trt) and time after infusion. Panel C shows S100A8 concentration $(* P=0.0023)$, panel D shows SCC $(* P=0.0001)$, and panel E shows percentage $(P=0.5216)$ and total of S100A8positive cells $\left({ }^{*} P<0.0001\right)$. Uninfused $=$ udders were uninfused; infused $=$ udders were infused with $100 \mu \mathrm{g}$ of LPS dissolved in $5 \mathrm{~mL}$ of saline $(\mathrm{n}=8)$. Results are reported as mean \pm SEM. 
localization. Cells collected from both blood and milk of uninfused goats were immunostained positively to S100A8 (Figure 3G and $\mathrm{H}$ ). This expression was also demonstrated in the blood leukocytes and milk somatic cells (Figure 2B). Moreover, S100A8 concentration was much higher in milk somatic cell-homogenized PBS than PBS alone (Figure 4A). These results strongly suggest that S100A8 is produced by leukocytes. This might support previous research revealing that S100A8 was found to constitute approximately $45 \%$ of the total cytosolic of neutrophils (Edgeworth et al., 1991). Furthermore, neutrophils constitute 45 to $75 \%$ of milk somatic cells of healthy goats, which is higher than that in bovines (Bergonier et al., 2003).

In the present results, the percentage of S100A8positive cells was significantly different between milk and blood $($ milk $=96.2 \pm 1.0 \%$, blood $=56.2 \pm 2.6 \%$; $P=0.0375$; Figure 4B). Differences among leukocytes, including their morphology, viability, and enzyme activities, which are originated from blood and milk, were extensively described in the bovine species (Prin-Mathieu et al., 2002; Paape et al., 2003). These differences might cause the different number of S100A8-positive cells in milk and blood.

The concentration of S100A8 in milk was measured before $(0 \mathrm{~h})$ and at $12,24,48,72,96,120$, and $144 \mathrm{~h}$ after infusion of LPS into the mammary gland. The intramammary challenge with LPS did not affect the mean concentration of S100A8 in milk during the entire experimental period by treatment (uninfused $=21.3 \pm$ $2.1 \mu \mathrm{g} / \mathrm{mL}$, infused $=22.8 \pm 1.9 \mu \mathrm{g} / \mathrm{mL}$, mean $\pm \mathrm{SE} ; P$ $=0.3324)$, but it was affected by time after infusion $(P$ $<0.0001)$, and an interaction between treatment and time $(P<0.0001)$ was observed once the mean concentration of S100A8 in milk was significantly higher at $72 \mathrm{~h}$ after the infusion of LPS (uninfused $=18.7$ $\pm 1.9 \mu \mathrm{g} / \mathrm{mL}$, infused $=33.0 \pm 4.1 \mu \mathrm{g} / \mathrm{mL}$, mean \pm SE; $P=0.0023$; Figure $4 \mathrm{C})$. The milk SCC started to increase at $12 \mathrm{~h}$ after LPS challenge and remained high until $144 \mathrm{~h}$ after infusion. The mean SCC was altered by treatment (uninfused $=3.0 \pm 0.1 \log _{10}$ SCC cells/ $\mathrm{mL}$, infused $=4.3 \pm 0.1 \log _{10} \mathrm{SCC}$ cells $/ \mathrm{mL}$, mean \pm SE; $P<0.0001)$, time after infusion $(P<0.0001)$, and interactions between treatment and infusion $(P=$ 0.0001; Figure 4D). The percentage of S100A8-positive cells in milk was not significantly different after intramammary infusion of LPS compared with $0 \mathrm{~h}(85.4 \pm$ $2.2 \%$, mean $\pm \mathrm{SE} ; P=0.5216$ ) even though the total number of S100A8-positive cells increased significantly $(P<0.0001)$. It is likely that S100A8-positive cells were associated with the increase of SCC (Figure 4E). In our previous report (Isobe et al., 2009b), SCC was increased even after saline infusion without LPS. However, SCC in the LPS-infused milk was much higher than in the saline-infused milk. Therefore, the effect of saline on the SCC in the present study must be limited. Taken together, it is demonstrated that S100A8 was not secreted immediately after LPS infusion but rather by gradual secretion until $72 \mathrm{~h}$. These results suggested that even though S100A8 concentration in milk was affected by LPS stimulation, the mechanism needs further study.

Before the infusion of LPS into the mammary gland, the concentration of S100A8 in milk ranged from 13 to $43 \mu \mathrm{g} / \mathrm{mL}$. This result suggested that S100A8 might be secreted spontaneously. As an unexpected result, a large difference of S100A8 concentration among animals before LPS infusion was present and may reflect the different immune status of goats. The significant variation in the abundance of S100A8 among animals was also expressed in the teat canal lining of cows, conceivably related to mastitis (Smolenski et al., 2015).

Production of S100A8 is known to be stimulated by proinflammatory cytokines such as TNF- $\alpha$, IFN- $\gamma$, and IL-1 $\beta$ in cultured keratinocytes (Mørk et al., 2003) and anti-inflammatory cytokine IL-10 in macrophages $(\mathrm{Xu}$ et al., 2001). The secretion of several AMP in the mammary gland is regulated in different regions and time courses after bacterial infection (Isobe, 2017). The cathelicidin-2 in milk increased at $4 \mathrm{~h}$ after the intramammary infusion of LPS (Zhang et al., 2014b), whereas lactoferrin increased at $2 \mathrm{~d}$ after infusion (Huang et al., 2012). Antimicrobial peptide S100A8 may be secreted in a coordinated pattern with other AMP to form the local defense against bacterial infection in the mammary gland. We conclude that S100A8 was produced in the leukocytes, and its secretion into milk was affected by LPS intramammary stimulation.

\section{REFERENCES}

Addis, M. F., S. Pisanu, G. Marogna, T. Cubeddu, D. Pagnozzi, C. Cacciotto, F. Campesi, G. Schianchi, S. Rocca, and S. Uzzau. 2013. Production and release of antimicrobial and immune defense proteins by mammary epithelial cells following Streptococcus uberis infection of sheep. Infect. Immun. 81:3182-3197.

Bahar, A. A., and D. Ren. 2013. Antimicrobial peptides. Pharmaceuticals (Basel) 6:1543-1575.

Bannerman, D. D. 2009. Pathogen-dependent induction of cytokines and other soluble inflammatory mediators during intramammary infection of dairy cows. J. Anim. Sci. 87:10-25.

Bergonier, D., and X. Berthelot. 2003. New advances in epizootiology and control of ewe mastitis. Livest. Prod. Sci. 79:1-16.

Bergonier, D., R. De Crémoux, R. Rupp, G. Lagriffoul, and X. Berthelot. 2003. Mastitis of dairy small ruminants. Vet. Res. 34:689-716.

Contreras, A., C. Luengo, A. Sanchez, and J. C. Corrales. 2003. The role of intramammary pathogens in dairy goats. Livest. Prod. Sci. $79: 273-283$.

Contreras, A., D. Sierra, A. Sanchez, J. C. Corrales, J. C. Marco, M. J Paape, and C. Gonzalo. 2007. Mastitis in small ruminants. Small Rumin. Res. 68:145-153.

Corbin, B. D., E. H. Seeley, A. Raab, J. Feldmann, M. R. Miller, V. J. Torres, K. L. Anderson, B. M. Dattilo, P. M. Dunman, R. Gerads, 
R. M. Caprioli, W. Nacken, W. J. Chazin, and E. P. Skaar. 2008. Metal chelation and inhibition of bacterial growth in tissue abscesses. Science 319:962-965.

Cremonesi, P., R. Capoferri, G. Pisoni, M. Del Corvo, F. Strozzi, R. Rupp, H. Caillat, P. Modesto, P. Moroni, J. L. Williams, B. Castiglioni, and A. Stella. 2012. Response of the goat mammary gland to infection with Staphylococcus aureus revealed by gene expression profiling in milk somatic and white blood cells. BMC Genomics 13:540.

Dore, S., M. Liciardi, S. Amatiste, S. Bergagna, G. Bolzoni, V. Caligiuri, A. Cerrone, G. Farina, C. O. Montagna, M. A. Saletti, M. L. Scatassa, G. Sotgiu, and E. A. Cannas. 2016. Survey on small ruminant bacterial mastitis in Italy, 2013-2014. Small Rumin. Res. 141:91-93.

Eckert, R. L., A. M. Broome, M. Ruse, N. Robinson, D. Ryan, and K. Lee. 2004. S100 proteins in the epidermis. J. Invest. Dermatol. 123:23-33.

Edgeworth, J., M. Gormanl, R. Bennett, P. Freemontl, and N. Hogg. 1991. Identification of $\mathrm{p} 8,14$ as a highly abundant heterodimeric calcium binding protein complex of myeloid cell. J. Biol. Chem. 266:7706-7713.

Elgawish, R. A., Y. Ogata, T. Hidaka, T. Nii, Y. Yoshimura, and N. Isobe. 2018. Changes in plasma concentrations of S100A7 and S100A8 in dairy cows during pregnancy. Reprod. Domest. Anim. 53:1013-1015.

Gebhardt, C., J. Ne'meth, P. Angel, and J. Hess. 2006. S100A8 and S100A9 in inflammation and cancer. Biochem. Pharmacol. 72:1622-1631.

Hayashi, N., J. Kido, R. Kido, C. Wada, M. Kataoka, Y. Shinohara, and T. Nagata. 2007. Regulation of calprotectin expression by interleukin-1alpha and transforming growth factor-beta in human gingival keratinocytes. J. Periodontal Res. 42:1-7.

Hsu, K., R. J. Passey, Y. Endoh, F. Rahimi, P. Youssef, T. Yen, and C. L. Geczy. 2005. Regulation of S100A8 by glucocorticoids. J. Immunol. 174:2318-2326.

Huang, Y. Q., K. Morimoto, K. Hosoda, Y. Yoshimura, and N. Isobe. 2012. Differential immunolocalization between lingual antimicrobial peptide and lactoferrin in mammary gland of dairy cows. Vet. Immunol. Immunopathol. 145:499-504.

Isobe, N. 2017. Control mechanisms for producing antimicrobial factors in ruminant mammary gland. Anim. Sci. J. 88:937-943.

Isobe, N., K. Hosoda, and Y. Yoshimura. 2009a. Immunolocalization of lingual antimicrobial peptide (LAP) in the bovine mammary gland. Anim. Sci. J. 80:446-450.

Isobe, N., J. Nakamura, H. Nakano, and Y. Yoshimura. 2009b. Intramammary challenge of lipopolysaccharide stimulates secretion of lingual antimicrobial peptide into milk of dairy cows. J. Dairy Sci. 92:6046-6051.

Isobe, N., A. Shibata, H. Kubota, and Y. Yoshimura. 2013. Lingual antimicrobial peptide and lactoferrin concentrations and lactoperoxidase activity in bovine colostrum are associated with subsequent somatic cell count. Anim. Sci. J. 84:751-756.

Kerkhoff, C., M. Klempt, and C. Sorg. 1998. Novel insights into structure and function of MRP8 (S100A8) and MRP14 (S100A9). Biochim. Biophys. Acta 1448:200-211.

McCormick, M. M., R. F. Rahimi, Y. V. Bobryshev, K. Gaus, H. Zreiqat, H. Cai, R. S. A. Lord, and C. L. Geczy. 2005. S100A8 and S100A9 in human arterial wall: Implication for atherogenesis. J. Biol. Chem. 280:41521-41529.

Mørk, G., H. Schjerven, L. Mangschau, E. Soyland, and P. Brandtzaeg. 2003. Cutaneous biology proinflammatory cytokines upregulate expression of calprotectin (L1 protein, MRP-8/ MRP-14) in cultured human keratinocytes. Br. J. Dermatol. 149:484-491.
Nishikawa, M., T. Nii, N. Isobe, and Y. Yoshimura. 2018. Investigation of the binding of goat cathelicidin-7 to lipopolysaccharide and leucocidal suppression of pro-inflammatory cytokines. Small Rumin. Res. 168:101-106.

Paape, M. J., D. D. Bannerman, X. Zhao, and J. W. Lee. 2003. The bovine neutrophil: Structure and function in blood and milk. Vet. Res. 34:597-627.

Paape, M. J., B. Poutrel, A. Contreras, J. C. Marco, and A. V. Capuco. 2001. Milk somatic cells and lactation in small ruminants. J. Dairy Sci. 84:237-244.

Perrin, G. G., and C. Baudry. 1993. Numérations cellulaires du lait de chèvre. Lait 73:489-497.

Prin-Mathieu, C., Y. Le Roux, G. C. Faure, F. Laurent, M. C. Bene, and F. Moussaoui. 2002. Enzymatic activities of bovine peripheral blood leukocytes and milk polymorphonuclear neutrophils during intramammary inflammation caused by lipopolysaccharide. Clin. Diagn. Lab. Immunol. 9:812-817.

Regenhard, P., W. Petzl, H. Zerbe, and H. Sauerwein. 2010. The antibacterial psoriasin is induced by $E$. coli infection in the bovine udder. Vet. Microbiol. 143:293-298.

Schauber, J., and R. L. Gallo. 2008. Antimicrobial peptides and the skin immune defense system. J. Allergy Clin. Immunol. 122:261266

Smolenski, G. A., R. T. Cursons, B. C. Hine, and T. T. Wheeler. 2015. Keratin and S100 calcium-binding proteins are major constituents of the bovine teat canal lining. Vet. Res. 46:113.

Smolenski, G. A., R. J. Wieliczko, S. M. Pryor, M. K. Broadhurst, T. T. Wheeler, and B. J. Haigh. 2011. The abundance of milk cathelicidin proteins during bovine mastitis. Vet. Immunol. Immunopathol. 143:125-130.

Souza, F. N., M. G. Blagitz, C. F. A. M. Penna, A. M. M. P. Della Libera, M. B. Heinemann, and M. M. O. P. Cerqueira. 2012. Somatic cell count in small ruminants, friend or foe? Small Rumin. Res. 107:65-75.

Srikrishna, G. 2012. S100A8 and S100A9: New insights into their roles in malignancy. J. Innate Immun. 4:31-40.

Srisaikham, S., W. Suksombat, Y. Yoshimura, and N. Isobe. 2016. Goat cathelicidin-2 is secreted by blood leukocytes regardless of lipopolysaccharide stimulation. Anim. Sci. J. 87:423-427.

Swanson, K., S. Gorodetsky, L. Good, S. Davis, D. Musgrave, K. Stelwagen, V. Farr, and A. Molenaar. 2004. Expression of a $\beta$-defensin mRNA, lingual antimicrobial peptide, in bovine mammary epithelial tissue is induced by mastitis. Infect. Immun. 72:7311-7314.

Vangroenweghe, F., I. Lamote, and C. Burvenich. 2005. Physiology of the periparturient period and its relation to severity of clinical mastitis. Domest. Anim. Endocrinol. 29:283-293.

Xu, K., T. Yen, and C. L. Geczy. 2001. IL-10 up-regulates macrophage expression of the S100 protein S100A8. J. Immunol. 166:63586366.

Zhang, G. W., S. J. Lai, Y. Yoshimura, and N. Isobe. 2014a. Messenger RNA expression and immunolocalization of psoriasin in the goat mammary gland and its milk concentration after an intramammary infusion of lipopolysaccharide. Vet. J. 202:89-93.

Zhang, G. W., S. J. Lai, Y. Yoshimura, and N. Isobe. 2014b. Expression of cathelicidins mRNA in the goat mammary gland and effect of the intramammary infusion of lipopolysaccharide on milk cathelicidin-2 concentration. Vet. Microbiol. 170:125-134.

Zhao, Y., H. Liu, X. Zhao, Y. Gao, M. Zhang, and D. Chen. 2015. Prevalence and pathogens of subclinical mastitis in dairy goats in China. Trop. Anim. Health Prod. 47:429-435. 